\title{
AUDIOTORI, VISUALISASI DAN PRAKTIK UNTUK MEMAHAMI MATERI TEORITIS PADA MATERI DASAR MULTIMEDIA BERDASARKAN LESSON STUDY
}

\author{
Gerlan A. Manu' ${ }^{1}$ Annajmi $^{2}$ \\ ${ }^{1}$ Sekolah Tinggi Keguruan dan Ilmu Pendidikan Citra Bina Nusantara \\ ${ }^{2}$ Universitas Pasir Pengaraian
}

\begin{abstract}
Abstrak
Penelitian ini didasari oleh model Lesson Study yang mengkaji pembelajaran Multimedia pada materi Objek-Objek Multimedia dan Perangkat Keras Multimedia yang bersifat materi teoristis. Peneliti menggunakan pembelajaran dengan audiotori, visualisasi dan praktik sebagai upaya untuk memahami materi teoristik pada materi dasar Multimedia. Pada umumnya materi teoristik atau materi pemahaman konsep suatu mata kuliah diajarkan dengan metode ceramah, contoh, dan penugasan. Hasil dari penelitian ini diperoleh materi teroristik dapat dipahami dengan baik oleh mahasiswa, karena terdapat penyajian materi yang bersifat audiotori, visual, dan praktik. Pada pembelajaran materi dasar multimedia ini, mahasiswa diminta untuk mendengarkan audio, menebak suara dari file audio tersebut, menonton video dan melakukan praktik untuk memahami konsep dasar dari objek-objek multimedia dan memahami penggunaan dari perangkat keras multimedia.
\end{abstract}

Kata Kunci : Lesson Study, Model Pembelajaran, Audiotori, Visualisasi, Praktik, Materi Teoristik

\section{A. PENDAHULUAN}

Mahasiswa saat ini adalah mahasiswa Generasi $\mathrm{Z}$ yaitu generasi yang lahir antara tahun 1995-2012. Generasi Z sering disebut 'Technoholic' karena ketergantungannya pada teknologi yang sangat tinggi [1]. Seiring dengan pesatnya perkembangan teknologi berpengaruh pada gaya belajar mahasiswa generasi $\mathrm{Z}$. Mahasiswa mengandalkan kecepatan informasi yang instan, informasi dapat diakses dengan mudah dan cepat oleh mahasiswa sehingga materi perkuliahan yang bersifat teoristik dengan mudahnya dapat diketahuinya.

Perkembangan

zaman

mempengaruhi gaya belajar mahasiswa generasi Z. Gaya belajar mahasiswa generasi $Z$ terdiri dari 3 hal yaitu mahasiswa generasi $\mathrm{Z}$ membutuhkan tujuan yang jelas di awal pembelajaran, mahasiswa generasi $\mathrm{Z}$ menyukai metode learning by doing, mahasiwa generasi $\mathrm{Z}$ umumnya memiliki kemampuan multitasking[1]. Dengan 3 hal tersebut maka disimpulkan mahasiswa generasi $\mathrm{Z}$ umumnya lebih menyukai gaya belajar yang bersifat eksperimen dan melakukan praktik daripada hanya sekedar duduk mendengarkan teori di kelas. Saat mahasiswa generasi $\mathrm{Z}$ merasa bosan dalam pembelajaran dengan kemampuan multitasking, mahasiswa dapat melakukan hal lain tanpa diketahui oleh dosen seperti mengakses aplikasi chatting atau media sosial pada smartphone. Untuk itu maka, pendidikan diharapkan secara sadar mampu mempersiapkan peserta didik dengan kegiatan pembelajaran yang sesuai dengan tantangan zaman pada masa depan [2].

Menurut Yusri Wahyuni, Dosen sebagai tenaga pengajar di tingkat perguruan tinggi harus memiliki strategi mengajar yang cocok untuk mengakomodasi gaya belajar setiap mahasiswa. Dengan melibatkan aspek visual, auditorial, dan kinestetik diharapkan mampu meningkatkan aktifitas belajar mahasiswa di kelas [3]. Menurut 
Siti Nurannisaa P.B, Penggunaan Visual dalam proses pembelajaran membuat pembelajaran lebih mudah untuk memahami konsep dan meningkatkan ingatan, namun untuk menghasilkan perangkat visual tersebut diperlukan pengetahuan dan keterampilan dalam merancang visual, dan menggunakan visual [4].

Pada penelitian ini mengungkapkan proses pembelajaran mata kuliah Multimedia. Materi perkuliahan Multimedia pada program studi Pendidikan Teknik Informatika, Universitas Negeri Malang terdiri dari teori dan praktik. Materi pada pertemuan awal mata kuliah Multimedia umumnya bersifat teoristis. Pada pertemuan ketiga yaitu objek-objek multimedia, dengan tujuan pembelajarannya adalah mahasiswa mampu memahami objek-objek multimedia seperti teks, image, animasi, audio, dan video. Dan pada pertemuan keempat yaitu perangkat keras multimedia, dengan tujuan pembelajarannya adalah mahasiswa dapat mengetahui perangkat keras multimedia. Seringkali materi bersifat teoristis ini diajarkan dengan metode ceramah, contoh, dan penugasan. Kegiatan praktik, baru akan dilaksanakan pada pertemuan di tengah semester atau pada akhir semester untuk materi praktiknya. Berdasarkan karakteristik mahasiswa generasi $\mathrm{Z}$ maka mahasiswa perlu lebih sering dilatih dalam hal praktik multimedia pada setiap pertemuan atau setiap pembahasan materi, baik dalam materi teoristik maupun materi praktik. Hal ini menuntut dosen untuk dapat menerapkan model pembelajaran yang mampu melatih keahlian/skill dari mahasiswanya tentang multimedia. Dituntut model pembelajaran yang sesuai dengan karakteristik dari mahasiswa generasi $\mathrm{Z}$ yang menekankan pada kemampuan berpikir logis, analisis, kritis, inovatif dan kreatif.

Dengan Lesson Study $(L S)$ persiapan, perlaksanaan, dan evaluasi pada pembelajaran dapat dilakukan secara kolaboratif dan berkelanjutan [5]. Dosen dapat saling membantu dalam komunitas belajar untuk mempersiapkan, melaksanakan dan mengevaluasi pembelajaran mata kuliah yang diampuhnya. LS mampu membentuk kelompok belajar yang kreatif dan inovatif, karena dosen dapat saling memberikan ide-ide baru dalam mempersiapkan perkuliahan. Dosen dapat mengetahui kekurangan dan kelebihan dari dirinya dari hasil evaluasi kelompok belajar terhadap pelaksanaan pembelajaran yang dilakukannya di kelas. Hal ini memberikan semangat dalam meningkatkan kualitas diri dosen. Pada LS terdapat 3 tahapan yaitu Plan, Do, dan See. Tahap Plan dilakukan secara kolaboratif pendidik merencanakan pembelajaran berpusat pada peserta didik. Tahap Do, seorang pendidik melaksanakan pembelajaran yang berpusat peserta didik. Sementara pendidik lainnya mengobservasi kegiatan pembelajaran peserta didik. Tahap See, dilakukan secara kolaboratif pendidik merefleksikan keefektifan pembelajaran dan saling belajar dengan prinsip kolegalitas[5].

Penelitian ini dilakukan pada masa program magang dosen kemenristekdikti di Universitas Negeri Malang tahun 2018. Peneliti adalah peserta program magang dosen (dosma) dan juga sebagai dosen model. Peneliti melibatkan pengampu mata kuliah Multimedia dan beberapa dosma dari program studi lain sebagai observer. LS dilakukan dengan 2 siklus. Siklus 1 dengan materi objek-objek multimedia, dan siklus 2 dengan materi perangkat keras multimedia. Peserta didik adalah mahasiswa semester 5 kelas B program studi Pendidikan Teknik Informatika, Universitas Negeri Malang. Untuk kedua siklus tersebut, proses plan pertama, dilakukan bersama dosen pengampu untuk membahas materi yang akan dibawakan dalam proses pembelajaran pada siklus 1 dan siklus 2 . Proses plan kedua dilakukan bersama beberapa dosen magang (dosma). Proses do, dilakukan pada dua kali pertemuan 
secara berturut-turut dengan para observer mengamati proses pembelajaran. Proses see, dilakukan refleksi keefektifan pembelajaran, membahas tentang hasil pengamatan para observer. Pada proses see, dibahas tentang kekurangan dan kelebihan yang terjadi pada proses pembelajaran tersebut untuk pembaharuan pelaksanaan LS berikutnya.

\section{B. METODE PENELITIAN}

Metode dalam penelitian ini adalah metode kualitatif deskriptif. Teknik pengumpulan data dalam penelitian ini dilakukan berbasis Lesson Study untuk mata kuliah Multimedia pada program studi Pendidikan Teknik Informatika semester 5 kelas B tahun ajaran 2018/2019 Universitas Negeri Malang. Data diperoleh dari pelaksanaan plan, do, dan see. Sumber data yaitu materi ajar, lembar observasi yang telah diisi oleh observer, lembar kerja mahasiswa, umpan balik dari mahasiswa, hasil foto, dan hasil rekaman/ video. Pihak yang terlibat dalam penelitian ini adalah dosen pengampu mata kuliah multimedia, 39 orang mahasiswa semester 5 kelas B, dan kelompok LS yaitu beberapa dosma dari program studi yang berbeda.

Dalam penelitian ini dilakukan pemeriksaan keabsahan data penelitian melalui teknik triangulasi. Teknik triangulasi dilakukan dengan cara membandingkan hasil observasi dari para observer yang ada untuk keperluan pengecekan kembali tingkat kepercayaan data. Teknik analisa data yang dilakukan dalam penelitian ini, dilakukan dengan langkah-langkah sebagai berikut :

1. Mengumpulkan data penelitian yang ada mulai dari tahap plan, do, dan see pada lesson study proses pembelajaran objek-objek multimedia dan perangkat keras multimedia.

2. Mengklasifikasikan data tersebut menurut pembagiannya.

3. Mengiventarisasikan data berupa hasil foto dan rekaman/ video dari tahap plan, do, dan see pada lesson study proses pembelajaran objek-objek multimedia dan perangkat keras multimedia.

4. Menghubungkan data penelitian mulai dari tahap plan, do, dan see pada lesson study proses pembelajaran objek-objek multimedia dan perangkat keras multimedia.

5. Mendeskripsikan data lesson study berdasarkan temuan penelitian yang akan menjadi kesimpulan dari hasil penelitian ini.

\section{HASIL DAN PEMBAHASAN \\ Siklus 1. Proses pembelajaran objek- objek multimedia}

Proses plan, dilakukan dua kali. Pada proses plan pertama, peneliti yang sekaligus sebagai dosen model membahas materi ajar multimedia dengan dosen pengampu mata kuliah Multimedia, Bpk Hakkun Elmunsyah, MT. Diperoleh materi ajar yang akan dibawahkan oleh dosen model pada siklus pertama adalah objek-objek multimedia, yang membahas tentang teks, gambar, animasi, audio, video, dan pencahayaan. Dan pada siklus kedua, materi ajar yang akan dibawakan yaitu tentang perangkat keras multimedia. Pada proses plan kedua, peneliti bersama kelompok LS membahas perencanaan proses pembelajaran yang akan dilaksanakan pada tanggal 4 September 2018. Berikut adalah beberapa catatan diskusi kelompok LS pada plan kedua tersebut :

1. Mahasiswa diminta untuk menuliskan nama pada kertas stiky (kertas tempel) dan menempelnya di dada atau bahu.

2. Materi disajikan secara kompleks/lengkap di powerpoint, namun penjelasan per materi di kelas disampaikan dengan ringkas dijelaskan menggunakan contoh yang menarik perhatian mahasiswa.

3. Tidak hanya teori yang disampaikan oleh dosen tetapi Dosen juga memberikan praktik dan mengerjakan latihan di Lembar Kerja Mahasiswa.

4. Dengan banyaknya materi yang akan disampaikan dalam pertemuan ini, 
pengerjaan latihan dikerjakan per kelompok.

5. Memberikan motivasi bagi mahasiswa tentang implementasi multimedia dalam dunia kerja.

Berdasarkan beberapa catatan plan tersebut, maka digunakan model pembelajaran Auditori, Visualisasi dan Praktik.

Pada proses do, peneliti sebagai dosen model melakukan proses pembelajaran di Lab Multimedia program studi pendidikan teknik informatika pada tanggal 4 September 2018 dimulai tepat waktu pada pukul 07.00 hingga 11.30, sesuai dengan jadwal mata kuliah multimedia yang diatur oleh program studi. Para observer terdiri dari dosen pengampu mata kuliah multimedia Dr. Hakkun Elmunsyah, MT, dan kelompok LS yaitu Annajmi, S.Pd., M.Pd, Ilmiyati Rahmy Jasril, S.Pd., M.Pd.T, Vera Dewi Kartini Ompusunggu, S.Pd., M.Pd, dan Intan Kusumawati, S.Pd., M.Pd melakukan observasi sementara dosen model melakukan proses pembelajaran dengan materi objek teks, objek image, objek audio, objek video dan pencahayaan/lighting. Dalam proses pembelajaran, dosen model menyampaikan materi objek-objek multimedia secara singkat kemudian memberikan kesempatan pada mahasiswa untuk melakukan praktik sesuai dengan materi yang disampaikan, mengerjakan lembar kerja mahasiswa yang telah dipersiapkan, dan menonton film pendek yang memberikan motivasi bagi mahasiswa untuk dapat berkarya dalam bidang multimedia. Pada akhir perkuliahan mahasiswa diminta untuk menuliskan pendapatnya tentang pembelajaran yang diperolehnya hari ini pada bagian akhir lembar kerja mahasiswa tersebut.

Pada proses see, dilakukan evaluasi berdasarkan hasil pengamatan para observer yang kemudian dibandingkan dengan hasil foto dan hasil rekaman/video proses pembelajaran maka terdapat beberapa catatan pengamatan sebagai berikut :
1. Penulisan nama identitas pada kertas stiky sebagian tidak terlihat dengan jelas.

2. Terdapat beberapa mahasiswa di awal materi tidak fokus mengikuti perkuliahan.

3. Pada pembagian kelompok, jumlah anggota dalam kelompok bervariasi sehingga terdapat kelompok yang lebih banyak anggotanya. Lebih baik per kelompok maksimal 3 orang untuk menunjang keaktifan latihan dalam kelompok.

4. Posisi duduk kelompok tidak teratur dengan rapi.

5. Setiap latihan yang diberikan dilakukan evaluasi langsung oleh dosen model.

6. Terdapat mahasiswa yang diandalkan di kelompok sehingga peran mahasiswa lain dalam kelompok kurang.

7. Dosen Model menjawab pertanyaan dengan tenang dan memberikan penjelasan dengan baik.

8. Dosen Model memberikan candaan sehingga terdapat mahasiswa yang tetap bercanda dengan temannya, dalam mengerjakan latihan.

9. Adanya pemberian reward berupa snack Snickers menarik perhatian mahasiswa dan memacu mahasiswa untuk bisa mengerjakan latihan dengan lebih baik dan cepat. Efisiensi dan Efektifitas pengerjaan latihan menjadi meningkat.

10. Mahasiswa sangat tertarik saat uji mendengarkan suara dalam materi Audio.

11. Dosen Model memberikan motivasi kepada mahasiswa untuk lebih mempelajari multimedia melalui 2 video yaitu video cara pembuatan iklan dan film pendek hasil juara 1 Kompetisi Festival Film Mahasiswa Indonesia (FFMI) 2017 dari Universitas Timor.

12. Terlihat sebagian besar mahasiswa antusias menonton video yang diberikan. 
Berdasarkan proses plan, do dan see tersebut maka peneliti dapat mengambil kesimpulan untuk siklus 1 proses pembelajaran objek-objek multimedia ini terdapat beberapa hal sebagai berikut:

1. Pelajaran Berharga : materi ajar menggunakan model pembelajaran Auditori, Visualisasi dan Praktik sehingga memberikan aktivitas praktis dalam membangun keterampilan mahasiswa untuk memahami tentang Objek-Objek Multimedia. Mahasiswa memanfaatkan indera mata dan telinga untuk merenungkan, menciptakan dan memecahkan masalah.

2. Catatan tentang kekurangan dan kelebihan :

Kekurangan : kurang teratur dalam pembagian kelompok dan posisi duduk kelompok.

Kelebihan : penguasaan ilmu yang baik sehingga dapat memberikan penjelasan dengan tenang, dan langsung. Mampu menarik perhatian sebagian besar mahasiswa melalui sikap, contoh praktik, pemberian reward, dan hasil kerja multimedia dalam dunia kerja.

3. Ide dan Upaya untuk peningkatan kemampuan mahasiswa : malam mata kuliah yang bersifat praktik, sebaiknya kegiatan praktik dilakukan oleh masing-masing mahasiswa secara individu, jika harus berkelompok sebaiknya jumlah kelompok maksimal 3 orang.

\section{Siklus 2. Proses pembelajaran perangkat keras multimedia \\ Proses plan pada siklus 2,} pembahasan materi ajar antara dosen model bersama dosen pengampu sudah tidak lagi dilakukan karena sudah dilakukan pada siklus 1 . Sehingga peneliti yang sekaligus sebagai dosen model hanya melakukan pembahasan bersama kelompok LS. Pembahasan perencanaan proses pembelajaran yang akan dilaksanakan pada tanggal 17 September
2018 diperoleh beberapa catatan diskusi sebagai berikut :

1. Mahasiswa diminta untuk menuliskan nomor pada kertas stiky (kertas tempel) dan menempelnya di dada atau bahu.

2. Materi Perangkat Keras (Hardware) Multimedia bersumber dari buku hanya menjelaskan Perangkat Keras (Hardware) Multimedia pada umumnya, sedangkan seiring dengan perkembangan zaman, terdapat beberapa inovasi dalam Perangkat Keras (Hardware) Multimedia. Maka dari itu perlu disampaikan juga dalam perkuliahan tambahan materi tentang perkembangan Perangkat Keras (Hardware) Multimedia dan Inovasi Perangkat Keras (Hardware) Multimedia terkini.

3. Tidak hanya teori yang disampaikan oleh dosen tetapi Dosen juga memberikan praktik penggunaan Perangkat Keras (Hardware) Multimedia, dan memandu mahasiswa dalam mempraktikkannya.

4. Dalam pemahaman materi, diawal perkuliahan mahasiswa diminta untuk menuliskan apa saja yang diketahui tentang Perangkat Keras (Hardware) Multimedia oleh masing-masing mahasiswa. Setelah itu, materi disampaikan dan dibahas bersama. Kemudian pada akhir perkuliahan mahasiswa diminta untuk mengisi Lembar Kerja Mahasiswa tentang hal yang sama. Disini akan dilihat tentang perkembangan pemahaman materi tentang Perangkat Keras (Hardware) Multimedia.

5. Latihan pada perkuliahan ini dilakukan oleh masing-masing mahasiswa per individu.

6. Dosen memberikan motivasi bagi mahasiswa tentang implementasi multimedia dalam dunia kerja.

Berdasarkan materi ajar dan beberapa catatan plan tersebut, maka digunakan model pembelajaran untuk siklus 2 yaitu kombinasi Model 
Kontekstual, Model Demonstrasi dan Visualisasi.

Pada proses $d o$, peneliti sebagai dosen model melakukan proses pembelajaran di Lab Multimedia program studi pendidikan teknik informatika pada tanggal 17 September 2018 dimulai tepat waktu pada pukul 07.00 hingga 11.30. Para observer adalah kelompok LS yaitu Annajmi, S.Pd., M.Pd, Vera Dewi Kartini Ompusunggu, S.Pd., M.Pd, dan Intan Kusumawati, S.Pd., M.Pd melakukan observasi sementara dosen model melakukan proses pembelajaran dengan materi perangkat keras. Dalam proses pembelajaran, dosen model menyampaikan materi perangkat keras multimedia pada umumnya dan inovasi perangkat perangkat keras multimedia terkini, dengan menampilkan gambar dan video perangkat keras. Mahasiswa juga diberikan kesempatan untuk melakukan demonstrasi menggunakan salah satu inovasi perangkat keras multimedia yaitu gimbal kamera. Kemudian mahasiswa diminta untuk menuliskan kembali fungsi dan kegunaan dari perangkat keras multimedia yang baru diketahuinya dari pembelajaran hari ini pada lembar kerja mahasiswa yang telah dipersiapkan sebelumnya. Dan pada akhir perkuliahan mahasiswa diminta untuk menuliskan pendapatnya tentang pembelajaran yang diperolehnya hari ini pada bagian akhir lembar kerja mahasiswa tersebut.

Pada proses see, dilakukan evaluasi berdasarkan hasil pengamatan para observer yang kemudian dibandingkan dengan hasil foto dan hasil rekaman/video proses pembelajaran maka terdapat beberapa catatan pengamatan sebagai berikut :

1. Nomor yang dituliskan pada kertas stiky tidak dikumpulkan bersama Lembar Kerja Mahasiswa sehingga tidak bisa terpantau identitas dari nomor tersebut pada catatan observer.

2. Terdapat beberapa mahasiswa di awal materi tidak fokus mengikuti perkuliahan, ada yang diam-diam memainkan handphone, ada yang terlihat lelah dan mengantuk.

3. Mahasiswa yang terlambat diminta Dosen untuk menuliskan hasil review pekerjaan mahasiswa diawal perkuliahan di papan tulis.

4. Mahasiswa yang terlihat kurang fokus diminta Dosen untuk menjadi peraga di depan kelas, mempraktikkan cara pengambilan Video yang baik dan benar sesuai materi yang disampaikan, hal ini menarik perhatian mahasiswa.

5. Mahasiswa diberikan topik pembelajaran tentang Perangkat Keras yang berkaitan dengan kehidupan sehari-hari mahasiswa berdasarkan perkembangan zaman saat ini.

6. Dosen menggunakan alat atau perangkat keras Multimedia dalam hal ini Gimbal Camera milik sendiri untuk dapat digunakan mahasiswa dalam mempraktikkan penggunaan perangkat keras Multimedia.

7. Dosen menampilkan video cuplikan film "Iron Man" hal ini menarik perhatian mahasiswa, tampak beberapa mahasiswa bercerita dengan temannya saat dosen menyampaikan keterkaitan video tersebut dengan materi perkuliahan hari ini.

8. Dosen menampilkan video inovasi perkembangan perangkat keras Multimedia yang ternyata perkembangannya sudah mendekati seperti pada cuplikan film yang sebelumnya ditontonkan.

9. Lembar Kerja Mahasiswa diberikan pada akhir perkuliahan, untuk melihat sejauh mana mahasiswa mengikuti materi perkuliahan hari ini.

Berdasarkan proses plan, do dan see tersebut maka peneliti dapat mengambil kesimpulan untuk siklus 2 proses pembelajaran perangkat keras multimedia ini terdapat beberapa hal sebagai berikut:

1. Pelajaran Berharga : pembelajaran menggunakan model pembelajaran kombinasi Kontekstual, Demonstrasi, dan Visualisasi sehingga memberikan mahasiswa menjadi bersemangat dalam 
mengikuti perkuliahan karena turut terlibat mempraktikkan dan mahasiswa lainnya menyaksikan keterlibatan temannya. Disamping itu juga terdapat pembahasan yang berkaitan dengan perangkat keras multimedia yang digunakan sehari-hari oleh mahasiswa dalam hal ini smartphone mampu meningkatkan antusias mahasiswa dalam mengikuti perkuliahan.

2. Catatan tentang kekurangan dan kelebihan :

Kekurangan : tidak memperhatikan nomor yang tertulis pada kertas stiky dan tidak meminta untuk dikumpulkan bersama Lembar Kerja Mahasiswa untuk mengetahui identitas dari nomor tersebut.

Kelebihan : Dosen mampu mencairkan suasana di depan kelas dengan menunjukkan mahasiswa yang kurang aktif atau terlambat untuk berperan di kelas.

3. Ide dan Upaya untuk peningkatan kemampuan mahasiswa : dalam materi perkuliahan hari ini, mata kuliah bersifat teori dan praktik. Dalam kegiatan praktik yang dilakukan sebaiknya digilir permasing-masing mahasiswa, sehingga setiap mahasiswa dapat merasakan langsung bagaimana menggunakan perangkat keras multimedia tersebut.

\section{SIMPULAN}

Berdasarkan hasil penelitian pelaksanaan lesson study mata kuliah Multimedia program studi Pendidikan Teknik Informatika, tahun ajaran 2018/2019 di Universitas Negeri Malang, pelaksanaan lesson study telah dilakukan sesuai dengan prosedur lesson study di Indonesia, yaitu dengan tahap plan, do dan see. Ketiga tahap tersebut diperoleh model pembelajaran dengan audiotori, visualisasi dan praktik mampu mengaktifkan mahasiswa dalam kelas untuk memahami akan konsep-konsep teoristik dari objekobjek multimedia dan perangkat keras multimedia.

\section{DAFTAR PUSTAKA}

[1] Faiza Arum, Sabila J. Firda, dkk. 2018. Arus Metamorfosa Milenial. Penerbit Ernest : Kendal

[2] Amri, Sofan. (2013). Pengembangan \& Model Pembelajaran dalam Kurikulum 2013. Penerbit: Prestasi Pustaka : Jakarta

[3] Wahyuni Yusri. 2017. Identifikasi Gaya Belajar (Visual, Auditorial, Kinestetik) Mahasiswa Pendidikan Matematika Universitas Bung Hatta. Jurnal Penelitian dan Pembelajaran Matematika. Vol. 10 No. 2

[4] Nurannisaa P.B Siti. 2017. Menghadapi Generasi Visual; Literasi Visual Untuk Menstimulasi Kemampuan Berpikir Dalam Proses Pembelajaran. Jurnal Pendidikan dan Pembelajaran Sekolah Dasar. Volume 1 Nomor 2a.

[5] Susilo Herawati. 2013. Lesson Study sebagai sarana meningkatkan kompetensi pendidik. Makalah disajikan dalam Seminar dan Lokakarya PLEASE 2013 di Sekolah Tinggi Theologi Aletheia Jalan Argopuro 28-34 Lawang, tanggal 9 Juli 2013. 